\title{
Students' Potential Abilities as Correlates of Self- Employment Start-Up Intentions: Evidence from Private Sector-Led Technical and Vocational Education Institutions in Nigeria
}

\author{
James Edomwonyi Edokpolor \\ Benson Idahosa University, \\ Benin City, Edo State, Nigeria \\ Vero Iyalekhue Abusomwan \\ University of Lagos, \\ Yaba, Lagos State, Nigeria
}

\begin{abstract}
The current study examines the correlation between technical and vocational education and training (TVET) students' potential abilities and self-employment start-up intentions. The participants of the survey were 209 students of TVET institutions in Nigeria. Using a Bivariate Pearson Correlation Matrix and Simple Linear Regression tests of relationships, the results revealed a significant relationship between TVET students' potential abilities and self-employment start-up intentions. More specifically, the results revealed significant correlations among potential abilities (e.g., creativity and innovation skills, ICT functional literacy and numeracy skills, communication and collaboration skills, critical thinking and problem solving skills) and the intentions of TVET students to venture into self-employment upon graduation. The results also revealed significant correlations among potential abilities (e.g., managerial and leadership skills, flexibility and adaptability skills, lifelong learning and self-direction skills) and the intentions of TVET students to venture into self-employment upon graduation. Contrarily, the results revealed that there is no significant correlations among potential abilities (e.g., social and cross-cultural skills, desirability and feasibility skills) and the intentions of TVET students to venture into self-employment upon graduation. Implications, limitations and logical conclusions were spotted out in the study.
\end{abstract}

Keywords: education and training, self-employment start-up intention, students' potential abilities, technical education, vocational education. 


\section{Introduction}

Self-employment start-up intention is important for young individuals and societies, and self-employment start-up intention is described as a significant element for combating unemployment situation everywhere? However, the development of self-employment start-up intentions among young individuals is highly prioritized in knowledge-based economies, and as such, it is highly debated by policy makers as a strategy for curbing high rate of unemployment in many countries. In Nigeria, the National Bureau of Statistics (2018) reported that the rate of unemployment among young individuals (15-35 years old) has increased from $25.5 \%$ in the third quarter of 2017 , to $30.5 \%$ in the second quarter of 2018. This is a worrying trend to apparently all stakeholders in the country.

Researchers have also reported that unemployment is becoming rampant among technical and vocational education and training (TVET) students in Nigeria (Edokpolor \& Abusomwan, 2017; Olajide, 2015). This unpleasant situation required the TVET students to possess requisite skills (hereafter referred to potential abilities) so as to confidently venture into self-employment and lifelong learning. The essence of TVET is to produce graduates with pool of potential abilities to pursue professional careers (Wenstrom, Uusiautti \& Maatta, 2018). For students to possess potential abilities and succeed in their future entrepreneurial endeavour, they must continue to learn new skills through higher TVET (Nagele, Neuenschwander \& Rodcharoen, 2018). The intention to start-up a new business after graduation is an important decision for TVET students as it would help them to be self-employed and contribute to development of Nigerian economy.

After the completion of the initial TVET, only few out of every students might want to venture into self-employment. Self-employment start-up during the early stage of graduation from TVET depends on a wide-range of potential abilities possessed by students, which authors of this present study theorized as predictors of self-employment start-up intentions. The intention for selfemployment is therefore seen as a cognitive process driven by a wide-range of potential abilities possessed by students. Self-employment can be seen as utilizing one's acquired potential abilities to begin a business. Intention can be defined as a conscious state of mind that controls the attitude of people toward pursuing a specific task or a pathway toward achieving a specific task. Accordingly, self-employment intention is defined as a conscious arrangement to start-up a new business. This definition shows that the wide-range of potential abilities possessed by TVET students influence their intentions to startup a new business and also paves way for their further education.

Entrepreneurship scholars acknowledge that people who believe they possess a wide-range of potential abilities are determined to exert necessary effort of starting a business (Douglas \& Shepherd, 2002; Gatewood, Shaver, Powers \& Gartner, 2002). The authors of the present study argued from the resource-based perspective that a wide-range of potential abilities possessed by people dictates sustainable competitive advantage of their entrepreneurial firms (Barney, 1991). Human capital theory also depicted that people who possesses a wide-range of potential abilities achieve higher performance in their professional careers 
(Becker, 1975). These two theoretical assumptions upon which the present study is based suggest that the possession of a wide-range of potential abilities by the TVET students may influence their intentions for self-employment immediately after graduation.

Despite the recognition that a wide-range of potential abilities possessed by the TVET students may influence their intentions to start-up a new business, previous studies have scarcely investigated the relationship between students potential abilities and self-employment start-up intentions (Zarefard \& Beri, 2017), and to date there are inconsistencies in the conclusions reached (Kumara \& Kumar, 2010). The inconsistencies in the conclusions of earlier studies has accounted for the reason why Gorman, Hanlon and King (1997) suggested that more rigorous studies should be conducted by other researchers.

Earlier studies on the factors that influences students' intentions to start-up a new business focused on personality traits, which include, the need for achievement (McClelland, 1961), locus of control (Brockhaus, 1980), readiness to invest resources (Brockhaus \& Horowitz, 1986), tolerance of ambiguity (Begley \& Boyd, 1987), as well as, propensity to act (Shapero, 1975). Current studies have also focused on demographic variables of students, including, age, gender, education, vicarious experience, and experiences of change (Davidsson, 1995), as well as area of specialization, class, degree, batches, parent's occupation and family annual income (Kumara \& Kumar, 2010) as a variety of factors that influences self-employment convictions and intentions. More recently, selfefficacy beliefs have also been regarded as a significant factor, on the basis that individuals who believe they have the necessary personality attributes and characteristics start-up a new business venture and are more likely to do so (Baidi \& Suyatno, 2018; Mahmood, Sarfraz, Ramzan \& Abdullah, 2018; Ndofirepi, Rambe \& Dzansi, 2018; Travis \& Freeman, 2017).

A critical look at the literature, as exemplified above, revealed that the extent to which students' potential abilities influence their intentions to start-up a business and be self-employed has remained largely untested. It is evident that the extent to which students potential abilities, be they combinations of cognitive, non-cognitive and technical skills can influence the intentions to startup a new business requires further study. The present study therefore aims to assess the relationship between TVET students' potential abilities and the intentions for self-employment. The potential abilities required by TVET students to start-up a new business after graduation can be referred to as specific abilities, which include, communication and collaboration, creativity and innovation, managerial and leadership, life-long learning and self-direction, ICT literacy, social and cross-cultural, flexibility and adaptability, perceived desirability and feasibility, and critical thinking and problem solving.

The possession of the above-mentioned specific abilities is a crucial factor that influences the intentions to venture into a business, and TVET students are in a better chance to possess and utilize these specific abilities for self-employment after graduation. It is based on this importance that the Federal Government of Nigeria increased her interest to expand the scope of TVET by granting approval for the establishment of the private sector-led TVET institutions in her quest to 
complement effort of ongoing reforms in higher education sector in Nigeria (National Board for Technical Education, 2018). The bottom-line of this intervention was to equip young youths with the potential abilities to become self-employed or be employed in the informal sector (Kasali, 2015).

The TVET programmes introduced to provide young youths with ample opportunities to engage in entrepreneurial careers and lifelong learning are: banking operation, early child care education, networking and system security, refrigeration and air-conditioning, paralegal studies, film and TV production, innovative agriculture, computer software and software engineering, building construction, multimedia engineering, hospitality and tourism, performing and media arts, welding and fabrication, block laying and concreting, automotive mechatronics, and many others. Despite the effort to introduce these technical and vocational courses, unemployment rate in Nigeria is still on the increase (Edokpolor \& Owenbuigie, 2017). This precarious situation implies that most graduates from the numerous technical and vocational institutions are deficient of the potential abilities required to confidently start-up a business immediately after graduation.

Based on the alarming rates of unemployment and all manner of social ills in Nigeria, this research becomes very important in providing a better understanding of how potential abilities of TVET students can influence their intentions for self-employment. Therefore, this study seeks to empirically investigate the extent of relationship between TVET students' potential abilities and their self-employment start-up intentions. To achieve this aim, the study is further organized as follows. First, a conceptual model and hypotheses were developed. Second, the procedures used in conducting the study were described. Third, the data collected from respondents was analyzed and results were discussed. Fourth, the limitations of the study and suggestions for further studies were spotted out. Fifth, the research implications and recommendations for future practice were discussed. And finally, the conclusions arising from the research findings were logically drawn.

\section{Development of Research Model and Hypotheses}

The authors of this study begin this section with the development of a research model (see Figure 1) and hypothetical prepositions of all the major variables in the study. Specifically, the authors foretold the extent of relationship between the independent variables (i.e., TVET students' potential abilities), as well as, the dependent variable (i.e., self-employment start-up intentions). 


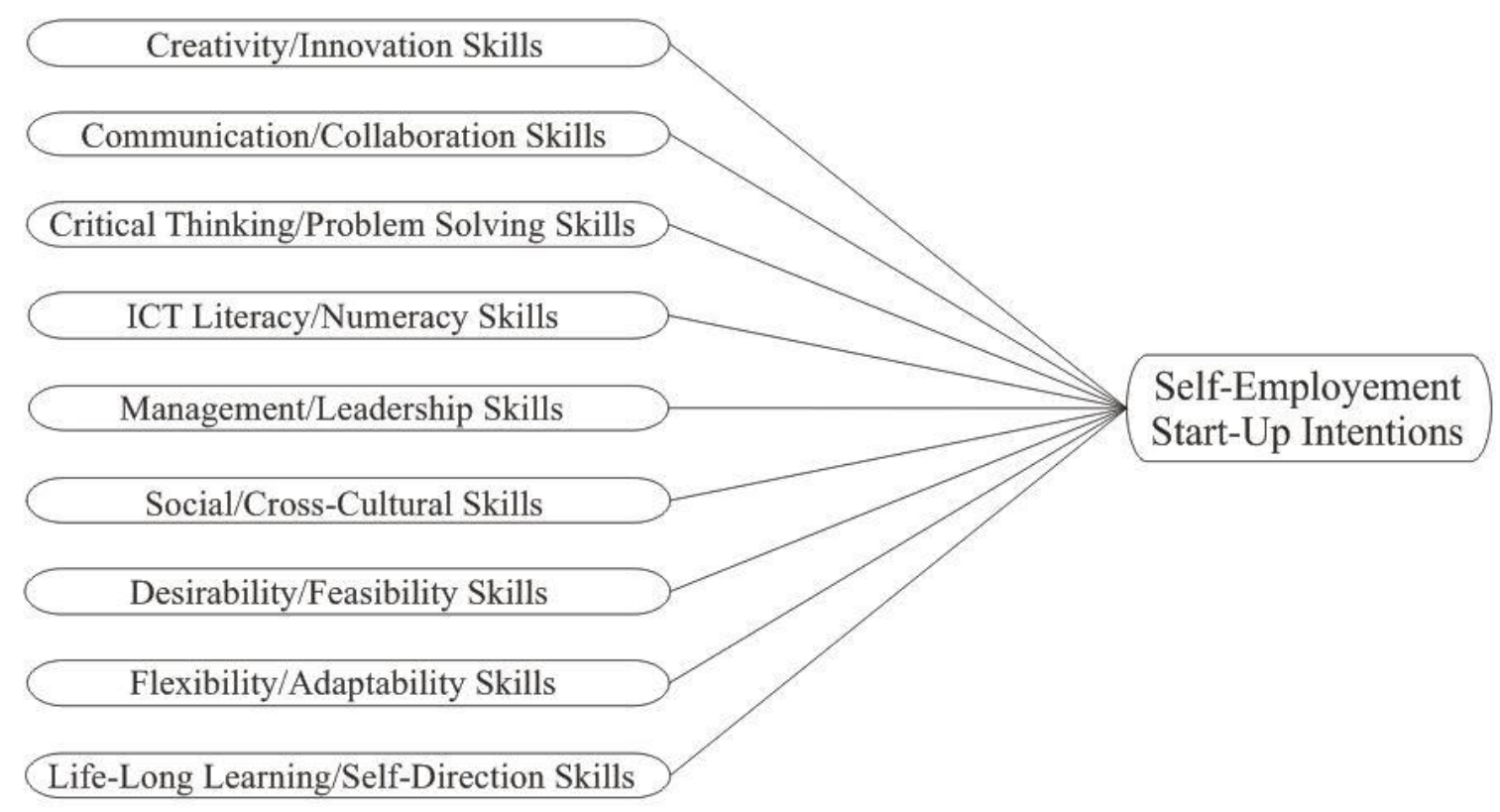

Figure I: Students Potential Abilities as Correlates of Self-Employment Start-Up Intentions

Source: Developed by the Authors

\subsection{Creativity and Innovation Skills and Self-Employment Start-Up Intentions}

Scholars have defined creativity as the ability to generate new and useful ideas (Certo \& Certo, 2006), whereas innovation is viewed as a procedure of including new thoughts into existing item or service (Amabile, 1996). These definitions provide an understanding for scholars to see both concepts as overlapping constructs (Petterson, 2005), implying that creativity is about thinking, and innovation is about doing. Creativity is seen as a central segment of innovation, which empowers people to take something inadequate or fragmented and transform it into something significant (Designer Reviver, 2009). It further incorporates slanting reasoning that foresees or predicts entrepreneurialism so as to interface inventiveness to business startup and create business venture dependent on imagination skills acquisition (Skillset, 2011). Joseph Schumpeter was the principal theorist to distinguish creativity as a noteworthy segment of an entrepreneurial venture, and further highlighted the importance of innovation to job creation (Schumpeter, 1934). Therefore, students who possess the ability to create and innovate something are seen as a creative thinkers and as product innovators, who are able to introduce something new and useful. The possession of creative and innovative skills is expected to influence intentions of students' for self-employment at some point in time; therefore, the authors of this study hypothesized that:

Hypotheses 1: The possession of creativity and innovation skills by TVET students will significantly influence their intentions for self-employment start-up. 


\section{Communication and Collaboration Skills and Self-Employment Startup Intentions}

Communication and collaboration skills are referred to as soft skills, or some of the main elements of generic skills as they can enable individual to communicate clearly, use oral, written, and non-verbal languages, and collaborate effectively and responsibly with diverse populations (Al-Alawneh, Hawamleh, Al-Jamal \& Sasa, 2019). As such, scholars have argued that such skills are required in the workplace as almost all jobs require interaction and collaboration with others (Gioiosa \& Kinkela, 2019). Scholars have specifically argued that communication skills are key success factor for the entrepreneurs in a variety of situations in convincing their business partners and presenting ideas, plans or products when dealing with clients (Kyndt \& Baert, 2015). Society therefore demands that young individuals should possess communication and collaboration skills because they have always been central to entrepreneurial success. Communication and collaboration skills are therefore essential abilities that contribute to individuals' ability to start a new business. These skills set provide young individuals the opportunity to enhance and practice negotiation skills in a more democratic business environment. Communication and collaboration skills are important for individuals to venture into entrepreneurial business, and indeed promote entrepreneurial behaviour. Possessing such abilities to interact and collaborate with others would influence the intention for self-employment, therefore the authors of this study hypothesized that:

Hypotheses 2: The possession of communication and collaborative skills by TVET students will significantly influence their intentions for self-employment start-up.

\section{Critical Thinking and Problem Solving Skills and Self-Employment Startup Intentions}

What does it mean to think critically? Michael Scriven, Richard Paul, and Linda Elder stated:

"Critical thinking is the intellectually disciplined process of actively and skillfully conceptualizing, applying, analyzing, synthesizing, and/or evaluating information gathered from, or generated by, observation, experience, reflection, reasoning, or communication, as a guide to belief and action." (Scriven \& Paul, 2008a).

"Critical thinking is that mode of thinking - about any subject, content, or problem - in which the thinker improves the quality of his or her thinking by skillfully analyzing, assessing, and reconstructing it. Critical thinking is self-directed, self-disciplined, self-monitored, and self-corrective thinking. It presupposes assent to rigorous standards of excellence and mindful command of their use." (Scriven \& Paul, 2008b).

"... Critical thinking is self-guided, self-disciplined thinking which attempts to reason at the highest level of quality in a fair-minded way. People who think critically consistently attempt to live rationally, reasonably, empathetically ... They use the intellectual tools that critical 
thinking offers - concepts and principles that enable them to analyze, assess, and improve thinking. They work diligently to develop the intellectual virtues of intellectual integrity, intellectual humility, intellectual civility, intellectual empathy, intellectual sense of justice and confidence in reason." (Elder, 2007)

The definitions provided above is thorough and informative, revealing that critical thinking is an intellectual virtue that can be acquired and stored in the mind of good thinkers. Problem solving on the other hand has been seen as a process of reaching a desired goal through the use of higher order skills to generate, interpret and appraise ideas, and using strategies to manage the complexity of situations. Vidergor (2015) states that critical thinking and problem-solving skills are $21^{\text {st }}$ century skills which students should possess to prepare them for the workplace. Thus, the integration of real-life learning into technical and vocational education curriculum is deemed beneficial as it would inculcate critical thinking and problem-solving skills on students that further influence their intentions to start-up their own business immediately after graduation. The possession of critical thinking and problem-solving skills is expected to influence students' intentions to venture into self-employment; therefore, the authors of this study hypothesized that:

Hypotheses 3: The possession of critical thinking and problem-solving skills possessed by TVET students will significantly influence their intentions for self-employment startup.

\section{ICT Literacy and Numeracy Skills and Self-Employment Startup Intentions}

Information and Communication Technology (ICT) literacy and numeracy skills entails the ability to get to, dissect and assess the intensity of the pictures, sounds and messages with which people are confronted each day and which assume a significant role in the creation and growth of entrepreneurial venture. They include the individual capacity to communicate using the media skillfully and competently. As such, the tremendous increase of ICT usage in the entrepreneurial sector has been vital in supporting the management of the sector and acting as a good source of change (Gerguri-Rashiti, Ramadhani, Abazi-Alili, Leo-Paul \& Ratten, 2015). However, scholars referred to ICT tools or gadgets as drivers and enablers of, or cornerstones for the advancement of the business sector (Apiyo \& Kiarie, 2018; Billon, Marco \& Lera-Lopez, 2017). The possession of ICT literacy and numeracy skills is expected to influence students' intentions to venture into self-employment; therefore, the authors of this study hypothesized that:

Hypotheses 4: The possession of ICT literacy and numeracy skills by TVET students will significantly influence their intentions for self-employment start-up. 


\section{Managerial and Leadership Skills and Self-Employment Startup Intentions}

Management expert, Peter Drucker, summed up managerial skills, as follow: set goals, organize activities, motivate people, measure performance and develop people (Daft, 2012). This means that managerial skills would help to perform a variety of tasks (e.g., planning, organizing, leading and controlling resources) so as to achieve organizational goals in an effective and efficient manner. Zarefard and Beri (2017) stated that any person in charge of managing a business should possess managerial skills, which includes organizational or technical skills. Managerial skills therefore are specialized skills which are important for managers. Arasti, Zandi and Talebi (2014) saw managerial skills as an important skills that determine the success or failure of a business. Managerial skills are used interchangeably with administrative skills and can be developed through training and natural setting. Blumberg and Pfann (2016) noted that the possession of managerial and leadership skills can influence students' convictions to choose self-employment as their career options. The following hypothesis is therefore propose for the study:

Hypotheses 5: The possession of managerial and leadership skills possessed by TVET students will significantly influence their intentions for self-employment start-up.

\section{Social and Cross-Cultural Skills and Self-Employment Startup Intentions}

The possession of social and cross-cultural skills through networks and other platforms can, in many cases or situations, enhances abilities of individuals to conduct themselves in a respectable and professional manner (Nisar, Prabhakar \& Strakovaa, 2019). Social and cross-cultural skills are active abilities for social marketing and advertising, including sales promotion that are used as platforms to serve institutions, businesses and people in many ways (Ganguly, 2015); gaining followers and posting news and pictures have effectively helped in the popularity and impact of business venture across the globe. The advantages of social network for sharing information, idea and connecting people have served the world both economically and socially (Alqahtani, 2019). As such, social and cultural skills are used to describe competencies and resources that are available to individuals by virtue of networks. Social and cultural skills can help individuals' to make decisions to start-up a new business by providing support and information. The possession of social and cross-cultural skills is expected to influence students' intentions to venture into self-employment; therefore, the authors of this study hypothesized that:

Hypotheses 6: The possession of social and cross-cultural skills possessed by TVET students will significantly influence their intentions for self-employment start-up.

\section{Desirability and Feasibility Skills and Self-Employment Startup Intentions}

Research on the intentions to start one's own business investigate the factors, such as: perceived desirability (perception of a personal appeal of starting a new business) and perceived feasibility (degree to which a person feels capable of 
doing so) (Peterman \& Kennedy, 2003). According to Shapero and Sokol (1982), perceived desirability is the attractiveness of starting a business, and perceived feasibility as the degree to which one possesses the capability of starting a business. They developed a model of entrepreneurial event formation, considering life changes to influence individual's perceptions of desirability and feasibility to start a business. This model assumes that life changes (e.g., displacement) influences peoples intentions for self-employment. Displacement can occur in negative form (e.g., unemployment) or positive form (e.g., possession of potential abilities). Thus, the intentions to start a new business and be self-employed depends on student's perceptions of desirability (e.g., 'do I want to do it?') and feasibility (e.g., 'do I have the skills to do it?') in relation to the intentions to start a new business. It means that perceived desirability and perceived feasibility are fundamental antecedents of self-employment start-up intentions. The following hypothesis is therefore propose for the study:

Hypotheses 7: The possession of desirability and feasibility skills possessed by TVET students will significantly influence their intentions for self-employment start-up.

\section{Flexibility and Adaptability Skills and Self-Employment Startup Intentions}

In a society where unemployment is high, the development of skills for entrepreneurial career is thought to be an important resource of individual's personal and professional life (Argyropoulou, Tsikoura \& Kaliris, 2017). However, the development of requisite skills would help individuals to be flexible and adaptable to societal changes coupled with the rapid technological advancements, globalization and contemporary global financial crisis. Some of the core skills to surmount unemployment issue may therefore include adaptability and flexibility skills. Students need to respond effectively to the high rate of unemployment through career adaptability and flexibility skills (Sidiropoulou-Dimakakou, Argyropoulou, Drosos, Kaliris \& Mikedaki, 2015).

Career adaptability is described as a multidimensional and psychosocial construct that includes attitudes, proficiencies and behaviours of individuals towards work life. It is seen as individual's readiness to respond to a conscious and continuous exploration of the self and the environment in order to cope with change of work roles and successfully handle unforeseen adaptations in career. Flexibility and adaptability resources help individuals to be optimistic about career pursuit; prepare for career pursuit; curious by formulating and exploring plans for career pursuit; strengthening the intentions to pursue career. As such, those individuals who possesses high adaptability resources may tend to exhibit the behavioural patterns that enable them to design the careers by attributing optimistic meanings to various career roles and ensure harmony in their personal and professional lives. Recently, career adaptability have been found to be significantly related to employment status and career success (Wilkins, Santilli, Ferrari, Nota, Tracey \& Soresi, 2014). The following hypothesis is therefore propose for the study:

Hypotheses 8: The possession of flexibility and adaptability skills possessed by TVET students will significantly influence their intentions for self-employment start-up. 


\section{Lifelong Learning and Self-Direction Skills and Self-Employment Start-Up Intentions}

Educators and researchers are increasingly showing interest in lifelong and selfdirected learning. Due to the increasing rate of unemployment, vocational educators and policy makers believe that lifelong and self-directed learning are beneficial in particular to those who possessed useful skills to start-up a business (Nagele, et al., 2018). The study conducted by Edokpolor and Chukwuedo (2018) showed that specific human capital variable (such as, lifelong learning and selfdirected abilities) are significantly correlated with core values of sustainable economic development (e.g., self-esteem, freedom and quality living). It has also been documented by self-regulation learning theorists (e.g., Schunk \& Zimmerman, 2008) that lifelong learning abilities (which include, self-direction and self-regulation learning) are predictors of career motivation (both in occupations and in learning). Therefore, the authors of the present study proposed the following hypothesis:

Hypotheses 9: The possession of lifelong learning and self-direction skills possessed by TVET students will significantly influence their intentions for self-employment startup.

\section{Research Methodology}

This section discusses the procedures that were used in achieving the purpose of the study. These procedures were described under the following headings: research design, research participants, research instrument, instrument validity and reliability, data collection method and data analysis.

\subsection{Research Design}

The study adopted a cross-sectional survey design and employed a correlational survey method in order to achieve the specific objectives of the study. The study aimed to assess the relationship between TVET students' potential abilities and their self-employment start-up intentions. This type of method "involves collecting data to determine whether, and to what degree, a relationship exists between two or more quantifiable variables" (Gay, Mills \& Airasian, 2009, p. 195). This correlational survey method would, therefore, enable the authors of the present study to establish the extent of relationship between the independent variables and dependent variable in the study.

\subsection{Research Participants}

The purposive sampling procedure were used to select 209 students of six TVET institutions in South-South geopolitical region of Nigeria who were voluntarily interested in participating in the study. By voluntary interest, the authors' of the study mean that TVET students were not forced or coerced to participate in the study, but they were encouraged by the authors', instructors and programme coordinators to participate in the study. The rationale for utilizing the purposive 
sampling technique is that students are not required to be forced or coerced before they respond to the research instruments.

\subsection{Research Instrument}

The instrument designed by the authors to obtain data from respondents is a 5point Likert scale questionnaire, consisting of 41 items, ranging from 4 (strongly agree) to 0 (strongly disagree). Items 1 to 6 assessed creativity and innovation skills, items 6 to 10 assessed communication and collaboration skills, items 11 to 16 assessed critical thinking and problem solving skills, items 17 to 21 assessed managerial and leadership skills, items 22 to 25 assessed social and crosscultural skills, items 26 to 31 assessed desirability and feasibility skills, items 32 to 33 assess flexibility and adaptability skills, items 34 to 35 assessed lifelong learning and self-direction skills, while items 36 to 41 assessed self-employment start-up intentions. For instance, a sample of the items raised for creativity and innovation skills is "I possessed the abilities to turn new and useful ideas into a marketable product and service". A sample of the items raised for communication and collaboration skills is "I possessed the abilities to build lasting relationships with customers". A sample of the items raised for critical thinking and problem solving skills is "I possesses the abilities to solve problems in conventional and innovative ways." A sample of the items raised for selfemployment start-up intentions is "I plan to start my own business right after graduation.

\subsection{Instrument Validity and Reliability}

The instrument was validated by two experts, one from Vocational Education and the other from Measurement and Evaluation. A reliability test was conducted in order to determine the internal consistency of the instrument, and the result showed a coefficient of .84 via Cronbach's alpha method.

\subsection{Data Collection Method}

The survey questionnaires were personally distributed to the respondents, with the assistance of six research collaborators from each TVET institutions. These research assistants were told what to do as regards the procedure to be followed in administering the research instrument to the respondents. The programme coordinators and students in the six TVET institutions were contacted via letter, before the research instruments were administered on respondents. Students in each of the institutions were assembled in a lecture hall and the research instruments were administered via direct contact mode. Students were sensitized as regards the contents of the research instrument and procedure to be followed when responding to the items of the research instrument. The students were allowed to complete the instrument and were given the chance to submit them in the lecture hall at their convenience.

\subsection{Data Analysis}

The data obtained from the respondents were analyzed using the IBM Statistical Package for the Social Scientists (SPSS) version 22.0. The bivariate correlation 
matrix and simple linear regression statistical tools were used to analyze the extent of relationship between the independent variables (i.e., TVET students' potential abilities) and the dependent variable (i.e., self-employment start-up intentions) of the study.

\section{Results}

The results of the data analyzed are presented in Tables 1 to 10 .

Table 1: Mean, Standard Deviations and Bivariate Pearson Correlation of the Study Variables

\begin{tabular}{clcccccccccccc}
\hline S/N Variables & $M$ & $S D$ & 1 & 2 & 3 & 4 & 5 & 6 & 7 & 8 & 9 & 10 \\
\hline 1. & CIS & 4.54 & .264 & 1 & & & & & & & & & \\
2. & CCS & 4.52 & .345 & $.390^{* *}$ & 1 & & & & & & & \\
3. & CTPSS & 4.57 & .365 & $.236^{* *}$ & $.242^{* *}$ & 1 & & & & & & \\
4. & ICTLNS & 4.51 & .431 & .128 & $.321^{* *}$ & .117 & 1 & & & & & \\
5. & MLS & 4.56 & .338 & $.310^{* *}$ & $.238^{* *}$ & $.177^{*}$ & $.223^{* *}$ & 1 & & & & \\
6. & SCCS & 4.55 & .357 & $.293^{* *}$ & $.241^{* *}$ & .038 & .021 & $.187^{* *}$ & 1 & & & & \\
7. & DFS & 3.86 & .430 & .088 & .099 & -.013 & -.051 & .072 & -.121 & 1 & & & \\
8. & FAS & 4.61 & .653 & .022 & $.155^{*}$ & .134 & $.140^{*}$ & $.280^{* *}$ & .123 & $-.285^{* *}$ & 1 & & \\
9. & LLLSDS & 4.52 & .658 & .045 & .125 & .108 & $.259^{* *}$ & $.163^{*}$ & $.242^{* *}$ & $-.234^{* *}$ & $.269^{* *}$ & 1 & \\
10. & SESI & 4.35 & .443 & $.172^{*}$ & $.212^{* *}$ & $.216^{* *}$ & $.162^{*}$ & $.257^{* *}$ & .083 & .001 & $.261^{* *}$ & $.263^{* *}$ & 1 \\
\hline
\end{tabular}

Note. $N=209, M=$ Mean, $S D=$ Standard Deviations, CIS = Creativity and Innovation Skills, CCS $=$ Communication and Collaboration Skills, CTPSS $=$ Critical Thinking and Problem Solving Skills, ICTLNS = ICT Functional Literacy Skills, MLS = Management and Leadership Skills, SCCS $=$ Social and Cross-Cultural Skills, DFS $=$ Desirability and Feasibility Skills, FAS $=$ Flexibility and Adaptability Skills, LLLSDS $=$ Life-Long Learning and Self-Direction Skills, SESI = Self-Employment Start-up Intentions.

The results presented in Table 1 showed the correlations between the study variables. The Table showed that the Mean responses of TVET students ranged from 4.51 to 4.86 , while the Standard Deviation values ranging from .264 to 658 . The Table also showed that the correlation coefficient of between the study variables ranged from 117 to .390 . These results are indications that TVET students' potential abilities positively correlates with self-employment start-up intentions.

Research Hypothesis 1: Creativity and innovation skills is significantly correlated with self-employment start-up intentions.

Table 2: Simple linear regressions of creativity and innovation skills as correlate of self-employment start-up intentions.

\begin{tabular}{lccccc}
\hline \multirow{2}{*}{ Intentions } & \multicolumn{5}{c}{ Creativity and Innovation Skills $\rightarrow$ Self-Employment Start-up } \\
\cline { 2 - 6 } & $B$ & SEB & Beta & $T$ & $P$ \\
\hline Constant & .042 & .523 & & 5.816 & .000 \\
CIS & .289 & .115 & .172 & 2.515 & .013 \\
\hline Note. $\mathrm{R}^{2}=.030$, Adjusted $\mathrm{R}^{2}=.025, \mathrm{~F}(1,207)=6.326, \mathrm{p}>.013$ & &
\end{tabular}


The results of the information introduced in Table 2 revealed that the level of creativity and innovation skills possessed by TVET students is significantly correlated with their intentions to venture into self-employment event right after graduation $(\mathrm{F}=6.326, \mathrm{t}=2.515, \beta=.172, \mathrm{p}>.013)$. The Table also revealed that the adjusted R-square (.025) depicts that $02.5 \%$ of variances in the intentions of TVET students to venture into self-employed business after graduation is determined by acquisition of creativity and innovation skills. Therefore, the research hypothesis is supported, which further implies that TVET students who possessed creativity and innovation skills will be motivated to start-up a selfemployed business immediately after graduation.

Research Hypothesis 2: Communication and collaboration skills is significantly correlated with self-employment start-up intentions.

Table 3: Simple linear regressions of communication and collaboration skills as correlate of self-employment start-up intentions.

\begin{tabular}{lccccc}
\hline \multirow{2}{*}{ Intentions } & \multicolumn{6}{c}{ Communication and Collaboration Skills $\rightarrow$ Self-Employment Start-up } \\
\cline { 2 - 6 } & $B$ & SEB & Beta & $T$ & $P$ \\
\hline Constant & .129 & .395 & & 7.928 & .000 \\
CCS & .271 & .089 & .212 & 3.115 & .002 \\
\hline
\end{tabular}

Note. $\mathrm{R}^{2}=.045$, Adjusted $\mathrm{R}^{2}=.040, \mathrm{~F}(1,207)=9.700, \mathrm{p}<.002$

The results of the information introduced in Table 3 revealed that the level of communication and collaboration skills possessed by TVET students is significantly correlated with their intentions to start-up self-employment event right upon graduation $(\mathrm{F}=9.700, \mathrm{t}=3.115, \beta=.212, \mathrm{p}<.002)$. The Table also revealed that the adjusted $\mathrm{R}$-square (.040) depicts that $04.0 \%$ of variances in the intention of TVET students to start-up self-employment event after graduation is accounted by the level of communication and collaboration skills possessed. Therefore, the research hypothesis is supported, which implies that TVET students who possessed communication and collaboration skills will be motivated to start-up a self-employed business immediately after graduation.

Research Hypothesis 3: Critical thinking and problem solving skills is significantly correlated with self-employment start-up intentions.

Table 4: Simple linear regressions of critical thinking and problem solving skills as correlate of self-employment start-up intentions.

\begin{tabular}{lccccc}
\hline \multirow{2}{*}{ Intentions } & \multicolumn{5}{l}{ Critical Thinking and Problem Solving Skills $\rightarrow$ Self-Employment Start-up } \\
\cline { 2 - 6 } & $B$ & SEB & Beta & $T$ & $P$ \\
\hline Constant & .156 & .377 & & 8.372 & .000 \\
CTPSS & .262 & .082 & .216 & 3.190 & .002 \\
\hline
\end{tabular}

Note. $\mathrm{R}^{2}=.047$, Adjusted $\mathrm{R}^{2}=.042, \mathrm{~F}(1,207)=10.176, \mathrm{p}<.002$

The findings of the information introduced in Table 4 revealed that the level of critical thinking and problem solving skills possessed by TVET students is significantly related with their intentions to start-up self-employment event right after graduation $(\mathrm{F}=10.176, \mathrm{t}=3.190, \beta=.216, \mathrm{p}<.002)$. The Table also revealed that the adjusted R-square (.042) depicts that $04.2 \%$ of variances in the intention of TVET students to start-up self-employment event after graduation is 
accounted by the level of critical thinking and problem solving skills possessed. Therefore, the research hypothesis is supported, which means that TVET students who possessed critical thinking and problem solving skills will exhibit the intention to start-up a self-employed business immediately after graduation.

Research Hypothesis 4: ICT literacy and numeracy skills is significantly correlated with self-employment start-up intentions.

Table 5: Simple linear regressions of ICT literacy and numeracy skills as correlate of self-employment start-up intentions.

\begin{tabular}{lccccc}
\hline \multirow{2}{*}{ Intentions } & \multicolumn{7}{c}{ ICT Literacy and Numeracy Skills $\rightarrow$ Self-Employment Start-up } \\
\cline { 2 - 5 } & $B$ & SEB & Beta & $T$ & $P$ \\
\hline Constant & .605 & .319 & & 11.304 & .000 \\
ICTLNS & .166 & .070 & .162 & 2.362 & .019 \\
\hline
\end{tabular}

Note. $\mathrm{R}^{2}=.026$, Adjusted $\mathrm{R}^{2}=.022, \mathrm{~F}(1,207)=5.579, \mathrm{p}>.019$

The results of the information introduced in Table 5 revealed that the level of ICT literacy and numeracy skills possessed by TVET students is significantly correlated with their intentions to start-up a self-employment event right after graduation $(\mathrm{F}=5.579, \mathrm{t}=2.362, \beta=.162, \mathrm{p}>.019)$. The Table also revealed that the adjusted R-square (.022) depicts that $02.2 \%$ of the variances in the intention of TVET students to start-up a self-employment event after graduation is determined by their level of ICT literacy and numeracy skills possessed. Therefore, the research hypothesis is supported, which implies that TVET students who possessed ICT literacy and numeracy skills will be motivation to start-up their own business immediately after graduation.

Research Hypothesis 5: Managerial and leadership skills is significantly correlated with self-employment start-up intentions.

Table 6: Simple linear regressions of managerial and leadership skills as correlate of self-employment startup intentions.

\begin{tabular}{lccccc}
\hline \multirow{2}{*}{ Intentions } & \multicolumn{5}{c}{ Managerial and Leadership Skills $\rightarrow$ Self-Employment Start-up } \\
\cline { 2 - 6 } & $B$ & SEB & Beta & $T$ & $P$ \\
\hline Constant & .815 & .403 & & 6.982 & .000 \\
MLS & .337 & .088 & .257 & 3.829 & .000 \\
\hline
\end{tabular}

Note. $\mathrm{R}^{2}=.066$, Adjusted $\mathrm{R}^{2}=.062, \mathrm{~F}(1,207)=14.658, \mathrm{p}<.000$

The findings of the information introduced in Table 6 revealed that the level of managerial and leadership skills possessed by TVET students is significantly correlated with their intentions to start-up a self-employment event immediately after graduation $(\mathrm{F}=14.658, \mathrm{t}=3.829, \beta=.257, \mathrm{p}<.000)$. The Table also revealed that the adjusted R-square (.062) depicts that $06.2 \%$ of variances in the intention of TVET students to start-up a self-employment event after graduation is accounted by the level of managerial and leadership skills possessed. Hence, the research hypothesis is supported, which further implies that TVET students who possessed managerial and leadership skills will be motivation to start-up a new business immediately after graduation.

Research Hypothesis 6: Social and cross-cultural skills is significantly correlated with self-employment start-up intentions. 
Table 7: Simple linear regressions of social and cross-cultural skills as correlate of self-employment start-up intentions.

\begin{tabular}{lccccc}
\hline \multirow{2}{*}{ Intentions } & \multicolumn{5}{c}{ Social and Cross-Cultural Skills $\rightarrow$ Self-Employment Start-up } \\
\cline { 2 - 5 } & $B$ & SEB & Beta & $T$ & $P$ \\
\hline Constant & .889 & .392 & & 9.917 & .000 \\
SCCS & .103 & .086 & .083 & 1.193 & .234 \\
\hline Note. $\mathrm{R}^{2}=.007$, Adjusted $\mathrm{R}^{2}=.002, \mathrm{~F}(1,207)=1.422, \mathrm{p}>.234$ &
\end{tabular}

The findings of the information introduced in Table 7 revealed that the level of social and cross-cultural skills possessed by TVET students is not significantly related to their intentions of starting a self-employment event right after graduation $(\mathrm{F}=1.422, \mathrm{t}=1.193, \beta=.083, \mathrm{p}>.234)$. The Table also revealed that adjusted R-square (.022) depicts that $02.2 \%$ of the variances in the intention of TVET students to startup self-employment event after graduation is determined by their level of social and cross-cultural ICT skills possessed. Therefore, the research hypothesis is not upheld, which further means that there is no significant relationship between social and cross-cultural ICT skills and selfemployment start-up intentions among TVET students.

Research Hypothesis 7: Desirability and feasibility skills is significantly correlated with self-employment start-up intentions.

Table 8: Simple linear regressions of desirability and feasibility skills as correlate of self-employment start-up intentions.

\begin{tabular}{lccccc}
\hline \multirow{2}{*}{ Intentions } & \multicolumn{5}{c}{ Desirability and Feasibility Skills $\rightarrow$ Self-Employment Start-up } \\
\cline { 2 - 5 } & $B$ & SEB & Beta & $T$ & $P$ \\
\hline Constant & .352 & .278 & 15.667 & .000 \\
DFSS & .001 & .072 & .001 & .010 & .992 \\
\hline Note. $\mathrm{R}^{2}=.000$, Adjusted $\mathrm{R}^{2}=.005, \mathrm{~F}(1,207)=0.000, \mathrm{p}>992$
\end{tabular}

Note. $\mathrm{R}^{2}=.000$, Adjusted $\mathrm{R}^{2}=.005, \mathrm{~F}(1,207)=0.000, \mathrm{p}>.992$

The results of the data provided in Table 8 revealed that the level of perceived desirability and feasibility studies skills possessed by TVET students is not significantly correlated with their intentions of starting a self-employment event right after graduation $(\mathrm{F}=0.000, \mathrm{t}=.010, \beta=.001, \mathrm{p}>.992)$. The Table also revealed that adjusted R-square (.005) depicts that $00.5 \%$ of the variances in the intention of TVET students to startup self-employment event after graduation is accounted by the level of perceived desirability and feasibility studies skills possessed. Hence, the research hypothesis is not supported, which further implies that there is no significant correlation between perceived desirability and feasibility studies skills and self-employment start-up intentions among TVET students.

Research Hypothesis 8: Flexibility and adaptability skills is significantly correlated with self-employment start-up intentions. 
Table 9: Simple linear regressions of flexibility and adaptability skills as correlate of self-employment start-up intentions.

\begin{tabular}{lccccc}
\hline \multirow{2}{*}{ Intentions } & \multicolumn{5}{c}{ Flexibility and Adaptability Skills $\rightarrow$ Self-Employment Start-up } \\
\cline { 2 - 6 } & $B$ & SEB & Beta & $T$ & $P$ \\
\hline Constant & .540 & .212 & & 16.695 & .000 \\
FAS & .177 & .046 & .261 & 3.883 & .000 \\
\hline Note. $\mathrm{R}^{2}=.068$, Adjusted $\mathrm{R}^{2}=.063, \mathrm{~F}(1,207)=15.079, \mathrm{p}<.000$
\end{tabular}

The findings of the information introduced in Table 9 revealed that the level of flexibility and adaptability skills possessed by TVET students is significantly correlated with their intentions of starting up a self-employment event immediately after graduation $(\mathrm{F}=15.079, \mathrm{t}=3.883, \beta=.261, \mathrm{p}<.000)$. The Table also revealed that the adjusted R-square (.063) depicts that $06.3 \%$ of variances in the intention of TVET students to startup self-employment event after graduation is accounted by the level of flexibility and adaptability skills possessed. Therefore, the research hypothesis is supported, which further implies that there is a significant relationship between flexibility and adaptability and self-employment start-up intentions among TVET students.

Research Hypothesis 9: Lifelong Learning and self-direction skills is significantly correlated with self-employment start-up intentions.

Table 10: Simple linear regressions of lifelong learning and self-direction skills as correlate of self-employment start-up intentions.

\begin{tabular}{lccccc}
\hline \multirow{2}{*}{ Intentions } & \multicolumn{5}{l}{ Lifelong Learning and Self-Direction Skills $\rightarrow$ Self-Employment Start-up } \\
\cline { 2 - 5 } & $B$ & SEB & Beta & $T$ & $P$ \\
\hline Constant & .555 & .206 & & 17.242 & .000 \\
MLS & .177 & .045 & .263 & 3.920 & .000 \\
\hline
\end{tabular}

Note. $\mathrm{R}^{2}=.069$, Adjusted $\mathrm{R}^{2}=.065, \mathrm{~F}(1,207)=15.362, \mathrm{p}<.000$

The findings of the information introduced in Table 10 revealed that the level of lifelong learning and self-direction skills possessed by TVET students is significantly correlated with their intentions of starting up a self-employment event immediately after graduation $(F=15.362, t=3.920, \beta=.263, p<.000)$. The Table also revealed that the adjusted R-square (.065) depicts that $06.5 \%$ of variances in the intention of TVET students to start-up self-employment event after graduation is accounted by the level of lifelong learning and self-direction skills possessed. Thus, the research hypothesis is supported, which further implies that TVET students who possessed lifelong learning and self-direction skills will be motivation to start-up a self-employed business immediately after graduation.

\section{Discussion}

The study aims at determining the correlation between students' potential abilities and their self-employment start-up intentions. The goal of the study is to provide empirical evidence that will help encourage TVET students to venture into self-employment at some point in life, due to the high rate of unemployment and every other social problems that have engulfed most 
graduates in Nigeria. The study contributed not only to the study of selfemployment intentions, but also provided support for the theories that explain the relevance of potential abilities among young individuals.

The test of hypothesis 1 depicts that creativity and innovation skills possessed by TVET students is significantly correlated with their intentions to venture into self-employed business upon graduation. To the researchers' knowledge, many studies that have been conducted in this area emerging inquiry agree with this current finding. For instance, the study conducted by Mugor (2017) and Zarefard and Beri (2018) revealed that ability to create and innovate have a significant influence on students self-employment intentions. The study conducted by Raju, Kumar and Ramgopalet (2015) also revealed that creativity and innovation skills has influence on students decisions to become self-employed. Camacho-Miñano and Del Campo (2017) further examined the influence of creative and innovative abilities on self-employment intentions and found a positive and significant relationship between them and self-employment intentions.

The test of hypothesis 2 reveals that the level of communication and collaboration skills possessed by TVET students is significantly correlated with their intentions to venture into self-employment. This finding do not support the study conducted by Zarefard and Beri (2017) who found that communication and collaboration skills do not prove to be significantly correlated with students intentions to venture into self-employment. The study conducted by Iksan, Zakaria, Meerah, Osman, Lian, Mahmud and Krish (2012) also showed that university students possessed good communication skills, which influences their intentions to start-up self-employed business.

Based on the outcome of hypothesis 3, the study showed a significant correlation between and among critical thinking and problem solving skills and TVET students' intentions to start-up a self-employed business. The result of the present study support the findings of Mugor (2017) which revealed that there was a positive and significant relationship between cognitive factors (e.g., critical thinking and problem solving skills) and students' self-employment intentions. This results implies that TVET programme have the capability of enhancing cognitive factors, such as critical thinking and problem solving skills which strongly influence self-employment intentions.

From the outcome of hypothesis 4, the study revealed that ICT functional literacy skills possessed by TVET students is significantly correlated with their intentions to start-up a self-employed business. The result of the present study do not support the findings of Chabongwa (2018) which revealed that TVET graduates do not have passion for entrepreneurship venturing, since they are not interested in becoming employers, but rather they want to work for other entrepreneurs. The study conducted by Chabongwa (2018) also revealed that TVET graduates are not experienced, and they do not have the requisite skills (including, ICT functional literacy and numeracy skills) to operate their own businesses and some exhibit lackadaisical attitude towards entrepreneurship venturing since they do not want to become risk takers and product innovators. 
Hypothesis 5 revealed that managerial and leadership skills possessed by TVET students is significantly correlated with their intentions to start-up a selfemployed business immediately after graduation. Although, a recent study have shown a direct relationship between individuals managerial and leadership abilities and organization's performance (Arasti, Zandi \& Bahmani, 2014). This finding invariably implies that the possessions of managerial and leadership abilities would influence TVET students' decisions to venture into self-employed business. In support of this assertion, the study conducted by Zarefard and Beri (2018) showed that managerial skills (of which leadership skill is a major component) positively and significantly predict entrepreneurial self-efficacy and attitudes toward innovative business start-up among university students.

From hypothesis 6, it was found that social and cross-cultural skills possessed by TVET students is not significantly correlated with their intentions to start-up a self-employed business. Unfortunately, this finding do not agree with the theoretical assumptions of Shapero and Sokol (1982) who established that entrepreneurial start-up intentions is formed or influenced by social and cultural context that individuals are exposed to. Empirically, the present finding do not also agree with the research conducted by Zarefard and Beri (2018) who found that social networking skills significantly predict convictions and attitudes toward business start-up among university students. Although, the finding disagree with the study of Ayalew and Zeleke (2018) who found that social networking skills and social contacts significantly influenced self-employment start-up intentions. They further found that social networking skills and professional contacts have a positive relationship with self-employment intentions at $5 \%$ level of significance.

Hypothesis 7 revealed that desirability and feasibility skills possessed by TVET students do not significantly influenced the intentions for self-employment upon graduation. Surprisingly, this present finding disagree with the assumptions of Shapero and Sokol (1982) which depict that entrepreneurial intentions is influenced by the perceived feasibility and perceived desirability of individuals. Empirically, research that examined perceived desirability and perceived feasibility of students have in fact found such abilities to positively and significantly predict entrepreneurial start-up intentions (Nguyen, 2017).

Based on the outcome of hypothesis 8 , the study showed a significant correlation between flexibility and adaptability skills and TVET students' intentions to venture into self-employed business. The result of the present study support the findings of Mugor (2017) which showed that there was a significant relationship between flexibility and adaptability skills and students' self-employment intentions. This result further implies that TVET programme have the capability of enhancing flexibility and adaptability skills which strongly influence selfemployment intentions.

Hypothesis 9 revealed that lifelong learning and self-direction skills possessed by TVET students are significantly correlated with their intentions to launch a self-employed venture upon graduation. This result is consistent with the 
findings of Edokpolor and Chukwuedo (2018) which depicted that lifelong learning skills (which include, self-direction and self-regulation skills) has influence on TVET students' perceptions to confidently pursue learning task throughout lifespan. The finding further support the assumption of social learning theory that lifelong learning, self-directed learning and self-regulated learning abilities are key determinants of learning motivation or academic success at the university level (Schunk \& Zimmerman, 2008).

\section{Limitations}

The main purpose of the study were achieved and the hypotheses were tested, although some limitations should be spotted out. However, the study has provided empirical evidence as regards correlation between TVET students' potential abilities and self-employment start-up intentions. First, because the study were conducted via a non-experimental procedure (i.e., a cross-sectional survey or by adopting a correlational survey design), causal inference could not be made in the study. The authors of the present study, therefore, recommend that longitudinal and experimental studies be conducted in order to provide better results. Second, because the sample size of participants was drawn from a private sector-led TVET programme in South-South, Nigeria, caution should be exercise in generalizing results of the present study. Therefore, future research should aim at employing proportional representative samples by covering broader geopolitical regions (e.g., South-East, South-West, North-East, NorthWest, and North-Central), to help in providing more balanced results from all private TVET institutions in Nigeria. Third, because the research participants are homogenous, which were private-led TVET students only, caution should be exercise in generalizing results of the present study to students in other academic disciplines. As such, these categories of students were use in the study because they are currently offering contemporary courses aimed at stimulating their intentions to engage in self-employment upon graduation. Hence, there is the need to embark on further research that include other categories of students from other technical and vocational-oriented educational institutions.

\section{Implications}

The present study depict that TVET students possesses some sort of potential abilities, and these differences tend to strongly influence their intentions or decisions to engage in self-employment upon graduation. The results of the present study, therefore, have implications for educational policy makers and researchers regarding the importance of TVET students' potential abilities. The study found a significant relationship between TVET students' potential abilities and their intentions to engage in self-employment upon graduation. It would therefore be very needful for managers of private sector-led TVET institutions to collaborate with other major stakeholders in order to ensure adequate supply of resources (both financially and otherwise) that would further help TVET 
students to possess potential abilities required for self-employment upon graduation.

\section{Conclusion}

The study found a significant correlation among communication and collaboration skills, critical thinking and problem solving skills, managerial and leadership skills, flexibility and adaptability skills, lifelong learning and selfdirection skills and self-employment start-up intentions. Based on these findings, the authors of the study concludes that the possession of potential abilities by TVET students will significantly influence their intentions for selfemployment start-up upon graduation. Even when the study found a significant relation between TVET students' potential abilities and self-employment startup intentions, the authors of the present study still suggest more rigorous study on the correlates of students' potential abilities and their self-employment startup intentions in other academic disciplines so as to ascertain if the results will be consistent.

\section{References}

Al-Alawneh, M. K., Hawamleh, M. S., Al-Jamal, D. A., \& Sasa, G. S. (2019). Communication skills in practice. International Journal of Learning, Teaching and Educational Research, 18(6), 1-19. https://doi.org/10.26803/ijlter.18.6.1

Alqahtani, A. S. (2019). Examining the relationship between academic leaders' communication skills and their social media usage. International Journal of Learning, Teaching and Educational Research, 18(6), 55-67. https://doi.org/10.26803/ijlter.18.6.4

Amabile, T. M. (1996). Creativity in context: Update to the social psychology of creativity. Boulder, CO: Westview Press.

Apiyo, R. O., \& Kiarie, D. (2018). Role of ICT tools in supply chain performance. International Journal of Supply Chain Management, 3(1), 17-26. Retrieved from https://www.iprjb.org/journals/index.php/IJSCM/article/view/598/739

Arasti, Z., Zandi, F., \& Bahmani, N. (2014). Business failure factors in Iranian SMEs: Do successful and unsuccessful entrepreneurs have different viewpoints? Journal of Global Entrepreneurship Research, 4(1), 10-21. https://doi.org/10.1186/s40497014-0010-7

Argyropoulou, K., Tsikoura, I., \& Kaliris, A. (2017). Career management skills of students in general and vocational upper-secondary schools in Greece: Career adaptability and self-efficacy in career planning. Baltic Journal of Career Education and Management, 5(1), 7-21. Retrieved from http://www.scientiasocialis.lt/bjcem/files/pdf/vol5/721.Argyropoulou_bjcem_Vol.5-1.pdf

Ayalew, M. M., \& Zeleke, S. A. (2018). Modeling the impact of entrepreneurial attitude on self-employment intention among engineering students in Ethiopia. Journal of Innovation and Entrepreneurship, 7(8), 1-27. https://doi.org/10.1186/s13731-0180088-1

Baidi., \& Suyatno. (2018). Effect of entrepreneurship education, self-efficacy and need for achievement toward student's entrepreneurship intention: Case study in FEBI, 
IAIN Surakarta, Indonesia. Journal of Entrepreneurship Education, 21(2), 1-16. https:// www.abacademies.org/articles/Effect-of-entrepreneurship-education1528-2651-21-2-161.pdf

Barney, J. B. (1991). Firm resources and sustained competitive advantage. Journal of Management, 17(1), 99-120. https:// doi.org/10.1177/014920639101700107

Becker, G. (1975). Human capital. NY: Columbia University Press.

Begley, T. M., \& Boyd, D. P. (1987). Psychological characteristics associated with performance in entrepreneurial firms and smaller businesses. Journal of Business Venturing, 2, 79-93. https://doi.org/10.1016/0883-9026(87)90020-6

Billon, M., Marco, R., \& Lera-Lopez, F. (2017). Innovation and ICT use by firms and households in the EU: A multivariate analysis of regional disparities. Information Technology and People, 30(2), 424-448. https://doi.org/10.1108/ITP-05-2015-0098

Blumberg, B. F., \& Pfann, G. A. (2016). Roads leading to self-employment: Comparing trans-generational entrepreneurs and self-made start-ups. Entrepreneurship Theory and Practice, 40(2), 335-357. http://ftp.iza.org/dp9155.pdf

Brockhaus, R. H. (1980). Risk-taking propensity of entrepreneurs. Academy of Management Journal, 23(3), 509-520. https://doi.org/10.5465/255515

Brockhaus, R., \& Horowitz, P. (1986). The psychology of the entrepreneur. In D. Sexton \& R. Smilor (Eds.). The art and science of entrepreneurship. Ballinger, Cambridge, MA.

Camacho-Miñano, M. D. M., \& Del Campo, C. (2017). The role of creativity in entrepreneurship: An empirical study on business undergraduates. Education + Training, 59(7/8), 672-688. https://doi.org/10.1108/ET-08-2016-0132

Certo, S. C., \& Certo, S. T. (2006). Modern management (10 th ed.). New Jersey: Upper Saddle River.

Chabongwa, N. (2018). The extent of entrepreneurship skills development through TVET Programmes in Botswana (Master's thesis). Faculty of Education, Bortho University, Botswana.

Daft, R. L (2012). New era of management (10 th ed.). Canada: South Western Cengage Learning.

Davidsson, P. (1995). Determinants of entrepreneurial intentions. Paper presented for the RENT IX Workshop. November 23-24, Piacenza, Italy.

Designer Reviver (2009). 10 essential skills every graphic designer should have. Retrieved from http://designreviver.com/articles/10-essential-skills-everygraphic-designer-should-have/.

Douglas, E. J. \& Shepherd, D. A. (2002). Self-employment as a career choice: Attitudes, entrepreneurial intentions, and utility maximization. Entrepreneurship Theory and Practice, 26(3), 81-90. https:// doi.org/10.1177/104225870202600305

Edokpolor, E. J., \& Abusomwan, I. V. (2017). Provision of equitable access to high-quality TVET programmes and development of human capital as correlates of equitable access to economic resources and poverty alleviation. International Journal of Gender Studies and Research, 5(1), 46-57.

Edokpolor, E. J., \& Chukwuedo, S. O. (2018). Technical and vocational education and training students' lifelong-career specific human capital: Gender consideration for sustainable development. International Journal of Gender Studies and Research, 6(1), 51-61.

Edokpolor, J. E., \& Owenvbiugie, R. O. (2017). Technical and vocational education and training skills: An antidote for job creation and sustainable development of Nigerian economy. Problems of Education in the 21st Century, 75(6), 535-549. Retrieved from http://oaji.net/articles/2017/457-1513710378.pdf 
Elder, L. (2007). Our concept of critical thinking (side bar), foundation for critical thinking. Retrieved

from http://www.criticalthinking.org/aboutCT/ourConceptCT.cfm

Ganguly, R. (2015). India's military: Evolution, modernization and transformation. India Quarterly, 17(3), 187-205. https:// doi.org/10.1177/0974928415584021

Gatewood, E. J., Shaver, K. G., Powers, J. B., \& Gartner, W. B. (2002). Entrepreneurial expectancy, task effort, and performance. Entrepreneurship Theory and Practice, 27(2), 187-206. https://doi.org/10.1111/1540-8520.00006

Gay, L. R., Mills, G. E., \& Airasian, P. (2009). Educational research: Competencies for analysis and applications ( $9^{\text {th }}$ ed.). Merrill, New Jersey: Upper Saddle River.

Gerguri-Rashiti, S., Ramadhani, V., Abazi-Alili, H., Dana. L., \& Ratten, V. (2015). ICT, innovation and firm performance: Transition economies. Thunderbird International Business Review, 59(1), 93-102. https://doi.org/10.1002/tie.21772.

Gioiosa, M. E., \& Kinkela, K. (2019). Classroom exercises with technology and communication skills: Students' perceptions. Journal of International Education in Business, 12(1), 2-13. https://doi.org/10.1108/JIEB-02-2018-0005

Gorman, G., Hanlon, D., \& King, W. (1997). Some research perspectives on entrepreneurial education, enterprise education and education for small business management: A ten year review. International Small Business Journal, 15(3), 56-77. https://doi.org/10.1177/0266242697153004

Iksan, Z. H., Zakaria, E., Meerah, T. S. M., Osman, K., Lian, D. K. C., Mahmud, S. N. D. \& Krish, P. (2012). Communication skills among university students. Procedia-Social and Behavioral Sciences, 59, 71-76. https://doi.org/10.1016/j.sbspro.2012.09.247

Kasali, J. A. (2015). Recipe for functional education system: Introduction of vocational enterprise institutions (VEI), innovation enterprise institutions (IEIs), national vocational certificate (NVC) and national vocational qualifications (NVQ). NABTEB Magazine. Special Edition.

Kumara, S. A. V., \& Kumar, Y. V. (2010). Examining entrepreneurial competencies and their relationship to self-employment intentions among engineering students: A case study from India. Industry $\mathcal{E}$ Higher Education, 24(4), 269-278. https://doi.org/10.5367/000000010792609763

Kyndt, E., \& Baert, H. (2015). Entrepreneurial competencies: Assessment and predictive value for entrepreneurship. Journal of Vocational Behaviour, 90, 13-25. https://doi.org/10.1016/j.jvb.2015.07.002

Mahmood, A., Sarfraz, M., Ramzan, M. A., \& Abdullah, M. I. (2018). Impact of creativity on entrepreneurial intentions through self-efficacy. International Journal of Humanities and Social Development Research, 2(1), 52-73. https://doi.org/10.30546/2523-4331.2018.2.1.52

McClelland, D. C. (1961). The achieving society. Princeton, New Jersey: Van Nostrand Co.

Murgor, T. K. (2017). Soft skills preparation as panacea for self-employment for TVET technician graduates in Kenya. International Journal of Vocational and Technical Education Research, 3(4), 18-34. Retrieved from http://www.eajournals.org/wpcontent/uploads/Soft-Skills-Preparation-as-Panacea-for-Self-Employment-forTvet-Technician-Graduates-in-Kenya.pdf

Nagele, C., Neuenschwander, M. P., \& Rodcharoen, P. (2018). Higher education in Switzerland: Predictors of becoming engaged in higher vocational or academic education - The role of workplace factors. International Journal for Research in Vocational Education and Training, 5(4), 264-284. https://doi.org/10.13152/IJRVET.5.4.2 
National Board for Technical Education (NBTE) (2018). Guidelines and procedures for the establishment of private technical and technological institutions in Nigeria. Programmes Department. Kaduna - Nigeria.

National Bureau of Statistics (2018). Labor force statistics volume I: Unemployment and underemployment report. Retrieved from https://www.proshareng.com/admin/upload/reports/12246Q32018unemploymentbyState-proshare.pdf

Ndofirepi, T. M., Rambe, P. \& Dzansi, D. Y. (2018). The relationship among technological creativity, self-efficacy and entrepreneurial intentions of selected South African university of technology students. Independent Research Journal in the Management Sciences, 18(1), 1-14. https:// doi.org/10.4102/ac.v18i1.544

Nguyen, C. (2017). Entrepreneurial intention of international business students in Viet Nam: A survey of the country joining the trans-pacific partnership. Journal of Innovation and Entrepreneurship, 6(7), 1-13. https://doi.org/10.1186/s13731017-0066-z

Nisar, T. M., Prabhakar, G., \& Strakova, L. (2019). Social media information benefits, knowledge management and smart organizations. Journal of Business Research, 94, 264-272. https://doi.org/10.1016/j.jbusres.2018.05.005

Olajide, S. E. (2015). Repositioning technical and vocational education toward eradicating unemployment in Nigeria. International Journal of Vocational and Technical Education, 7(6), 54-63. https://doi.org/10.5897/IJVTE2013.0142

Patterson, F. (2004). Personal initiative and innovation at work. In C. Spielberger (Ed.). Encyclopedia of Applied Psychology, 2, 843-855, US: Academic Press.

Peterman, N. E., \& Kennedy, J. (2003). Enterprise education: Influencing students' perceptions of entrepreneurship. Entrepreneurship Theory and Practice, 28(2), 129144. https:// doi.org/10.1046/j.1540-6520.2003.00035.x

Schumpeter, J. A. (1934). The theory of economic development. Cambridge, USA: Harvard University Press.

Schunk, D. H., \& Zimmerman, B. J. (Eds.) (2008). Motivation and self-regulated learning: Theory, research and applications. Mahwah, NJ: Erlbaum.

Scriven, M., \& Paul, R. (2008a). Defining critical thinking, foundation for critical thinking. Retrieved from: http://www.criticalthinking.org/aboutCT/definingCT.cfm

Scriven, M., \& Paul, R. (2008b). Our concept of critical thinking, foundation for critical thinking. Retrieved from: http://www.criticalthinking.org/aboutCT/ourConceptCT.cfm>

Shapero, A. (1975). The displaced, uncomfortable entrepreneur. Psychology Today, 133, 83-88.

Shapero, A., \& Sokol, L. (1982). Social dimensions of entrepreneurship. In C. Kent, D. Sexton, \& K. Vesper (Eds.). The encyclopedia of entrepreneurship. Englewood Cliffs, NY: Prentice Hall.

Sidiropoulou-Dimakakou, D., Argyropoulou, K., Drosos, N., Kaliris, A., \& Mikedaki, K. (2015). Exploring career management skills in higher education: Perceived selfefficacy in career, career adaptability and career resilience in Greek university students. International Journal of Learning, Teaching and Educational Research, 14(2), 36-52.

Skillset (2011). Sector skills assessment for the creative media industries in the UK. London: Oxford University Press.

Travis, K., \& Freeman, E. (2017). Predicting entrepreneurial intentions: Incremental validity of proactive personality and entrepreneurial self-efficacy as a moderator. Journal of Entrepreneurship Education, 20(1), 45-57. Retrieved from https://www.abacademies.org/articles/predicting-entrepreneurial-intentions- 
incremental-validity-of-proactive-personality-and-entrepreneurial-self-efficacyas-a-moderator-1528-2651-20-1-104.pdf

Vidergor, H. E. (2015). The multidimensional curriculum model. In H. E. Vidergor \& C. R. Harris (Eds.). Applied practice for educators of gifted and able learners. Rotterdam: Sense.

Wenstrom, S., Uusiautti, S., \& Maatta, K. (2018). The Force that keeps you going: Enthusiasm in vocational education and training (VET) teachers' work. International Journal for Research in Vocational Education and Training, 5(4), 244-263. https://doi.org/10.13152/IJRVET.5.4.1

Wilkins, K. G., Santilli, S., Ferrari, L., Nota, L., Tracey, T. J. G., \& Soresi, S. (2014). The relationship among positive emotional dispositions, career adaptability, and satisfaction in Italian high school students. Journal of Vocational Behaviour, 85, 329338. https://doi.org/10.1016/j.jvb.2014.08.004

Zarefard, M. \& Beri, S. E. C. (2017). Relationship between entrepreneurs' managerial competencies and innovative start-up intentions in university students: An Iranian case. Journal of Entrepreneurship Education, 21(3), 1-19. Retrieved from https://www.abacademies.org/articles/Relationship-Between-EntrepreneursManagerial-Competencies-and-Innovative-Start-Up-Intentions-in-UniversityStudents-An-Iranian-Case-1939-4675-21-3-107.pdf

Zarefard, M. \& Beri, S. E. C. (2018). Entrepreneurs' managerial competencies and innovative start-up intentions in university students: Focus on mediating factors. International Journal of Entrepreneurship, 22(2), 1-22. Retrieved from https://www.abacademies.org/articles/Entrepreneur s-managerialcompetencies-and-innovative-start-up-intentions-in-university-students-focuson-mediating-factors-\%201939-4675-22-2-141.pdf 